\title{
TOGETHER:THE COLLABORATIVE CURATORIAL PRACTICES OF A MUSEUM CURATOR, DRESS HISTORIAN AND FASHION DESIGN EDUCATOR
}

\author{
Jane Malthus, Moira White and Margo Barton
}

\section{INTRODUCTION}

The editors of Fashion Curating: Critical Practice in the Museum and Beyond argue that curatorial practice in dress and fashion changed in the later twentieth century, from a primarily custodial role in institutions where curators catalogued, archived and preserved works of art and fashion, to a wider exhibition role. While clearly museums have nearly always been sites of exhibition - of greatly varying focus, purpose and emphasis - in the fashion world, large retrospective exhibitions of designers' outputs have produced a higher public profile for their curators and brought new audiences flocking to museums. While fashion curators had traditionally been "anonymous labourers,"' a new type emerged following the example of Diana Vreeland, a special consultant at the Costume Institute, who had been a fashion journalist. ${ }^{2}$ Although her exhibitions from 1973 onwards were controversial, she led the way for curators, changing display practices and educational possibilities for fashion in museums. ${ }^{3}$

For the last 20 years and more, in various configurations, Jane Malthus, Margo Barton and Moira White have collaborated on dress and fashion research projects, curating exhibitions, writing articles and presenting conference papers, alongside our own individual research, curation and other pursuits. This paper documents and discusses our curatorial and research approaches in some of these collaborations. Most of these curatorial projects have been in museums, but some have taken place in non-traditional exhibition spaces. Jane is a dress historian, educator and curator who has catalogued and stored historical fashionable dress in museums for many years; Margo curates fashion events, as well as being a fashion educator; and Moira is a curator at Otago Museum, where she researches and writes about artifacts including dress. (See Appendix I for fuller biographies.)

While our collaborations have not been on the scale of international blockbuster shows, we see our curating as a critical collaborative enquiry, involving us in "shared endeavours, practically and intellectually."4 We aim to think imaginatively and critically, bring differing elements or viewpoints together, to spark conversations, ideas and viewers' own design dreams. In some of our collaborations, our primary aim is to support artists and designers to show their design outcomes to a wider audience. That audience is central to our endeavours. Our goal is always to allow people - be they fashion students and staff, anyone interested in clothes and, importantly, those who didn't know they were until they see them exhibited - to broaden and deepen their understanding of clothes and fashion. The 'how' and 'why' they were worn in the past, the social and cultural implications, design elements, textile variety and changes in manufacture, and issues of sustainability are all canvassed. Viewing a fashion exhibition may also spark a person's interest in fashion and contribute to how they may curate their fashioned selves in the future.

While we are constrained by the past collecting strategies of the Otago Museum - such as the bias towards female fashion and therefore consumerism - our experiences in exhibiting help inform policy changes for future acquisitions. ${ }^{5}$ Contributing to topical debates through the exhibition of clothing involves us as curators not only collaborating with each other, but with conservators, designers, institutions and audiences. The public produce 
meanings and create their own interpretations of the works. "Critical fashion curating is a way of producing knowledge which can visualise, display, and popularise fashion research in an accessible, even an 'edutaining, format while creating discourse."7

Curating exhibitions, whatever form they might take, involves processes of theme development, team creation, finding exhibition space, selection of content, designing and preparing the space, preparing items for presentation which in the case of garments involves deciding on the kinds of display forms to use - writing text for and creating labels and catalogues, installing, lighting, publicity, public programmes, then de-installing and assessing the exhibition and the process. ${ }^{8}$ In large exhibitions in public venues, such as our current exhibition, "Fashion Forward: Disruption Through Design," many people may collaborate on the work, but smaller exhibitions may see the curators doing it all. (See Appendix 2 for a list of the authors' curatorial collaborations and related publications.)

\section{EXAMPLES OF OUR COLLABORATIVE PRACTICE}

"Fashion Forward: Disruption Through Design" at Otago Museum started with a desire to show off the enormous creativity and design talent of emerging designers who had been finalists in the iD Dunedin International Emerging Designer Awards over the 17 years of its existence thus far. When Otago Museum approved the proposal for its exhibition schedule, the brief necessarily included artifacts from its large dress collection. We worked closely with the in-house design team on this exhibition, developing seven themes from the selected emerging designers' conceptual statements that we could then use to choose museum pieces. Those themes were escapism, gender, illusion, reinterpretation, sculptural, transformation and wellbeing. Part of our aim was to show that these themes had historical resonance: designers and makers had thought about these issues in the past as well as the present. A woman's going-away suit from the 1920 s embodied an 'escape' from spinsterhood to married life; a late-nineteenthcentury tea-gown allowed a woman to loosen her stays and relax for a time in the afternoon (this one also transformed a by-then out of fashion paisley shawl into a dress); and stiletto-heeled court shoes gave the illusion of longer, slimmer legs, or symmetrical feet!

Different kinds of display forms were used to differentiate museum objects from emerging designer outfits. Designers' garments were mounted on black shop mannequins with heads, while museum garments hung on headless dress forms or Fosshape structures. Other themes and ideas emerged too, such as the value of creativity, the talent and skill of makers, and the range of textiles and materials available and the inventive ways these have been treated and used. Implicit in such an exhibition are also stories: about the emerging designers themselves and their subsequent careers; about the owners, wearers, and makers of the historical pieces; about consumption patterns, changes in fashion and aesthetics, and sustainability concerns. Viewers voice their own nostalgia and stories when they see particular artifacts.

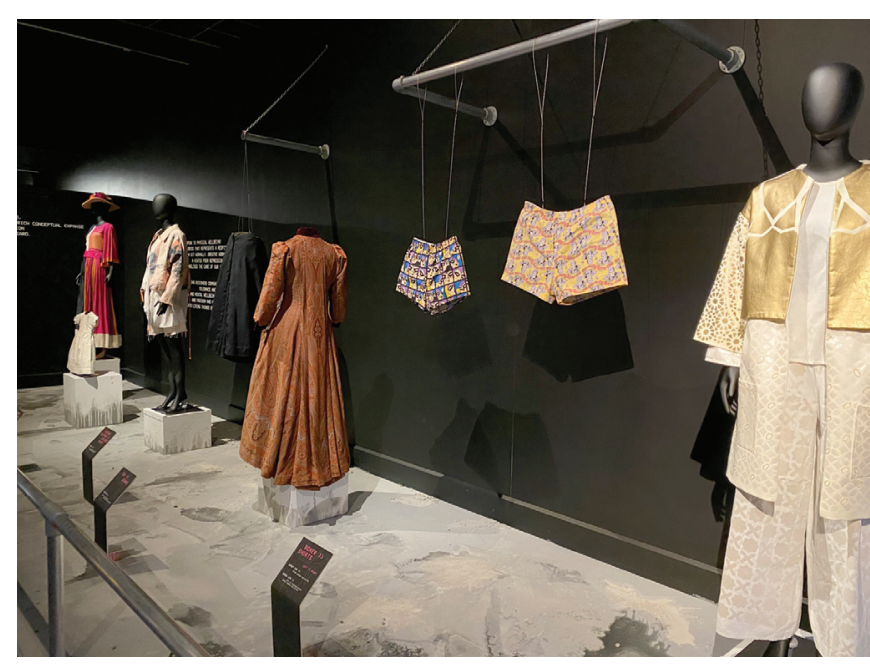

Figure I. Fashion FWD: Disruption through Design. Wellbeing section, showing the back of the tea-gown. Photograph: Jane Malthus. 
"Re:Emerging" at Dunedin Airport and "A Darker Eden; Fashion from Dunedin" at Silo Six in Auckland, were in effect, prototypes for "Fashion Forward." They were created in part to bring attention to the rich fashion design landscape of Dunedin, and to entice visitors to Dunedin to attend iD Dunedin Fashion Week events. Both exhibitions took place in spaces not traditionally used for fashion exhibits, a trend Vänskä and Clark highlighted and have practiced themselves: "As the practice of fashion curation extends into commercial galleries, public and retail spaces, and even to the individual self, professional concepts of 'curating' are undergoing rapid change."'

"A Darker Eden" was curated by a team from the School of Design, Otago Polytechnic, and featured fashion by some of the yet-to-betermed 'godmothers' included in "Fashion Forward:" high-profile, hard-working, then all Dunedin-based designers of NOM*d, Mild Red and Tanya Carlson, with Company of Strangers and Charmaine Reveley included as Otago Polytechnic fashion graduates. Large backdrops emphasised Dunedin's architecture and landscape.

"Re:Emerging" consisted of four cases with iD emerging designer finalists' garments and related museum artifacts shown on a large touch screen. We could not display museum dress artifacts in the small space of the airport exhibition, which also did not meet conservation requirements such as specified light and humidity levels. Instead, we had examples and text on a touch screen. Digital presentation of fashion - a wonderful adjunct, if not a completely satisfactory alternative to real objects - allows close-ups of garment details that cannot be seen so easily in a gallery display, inclusion of other images showing related work in context, and provides space for expanded textual information. We used touch screens again in "Fashion Forward."

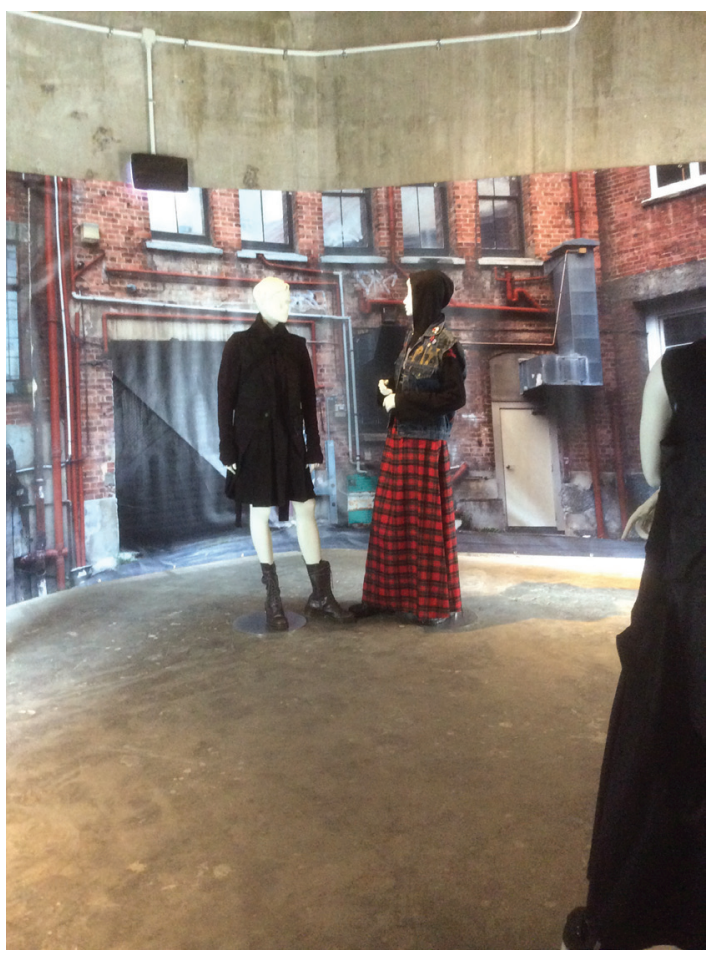

Figure 2. A Darker Eden, NOM*d garments and Dunedin buildings backdrop. Photograph: Jane Malthus.

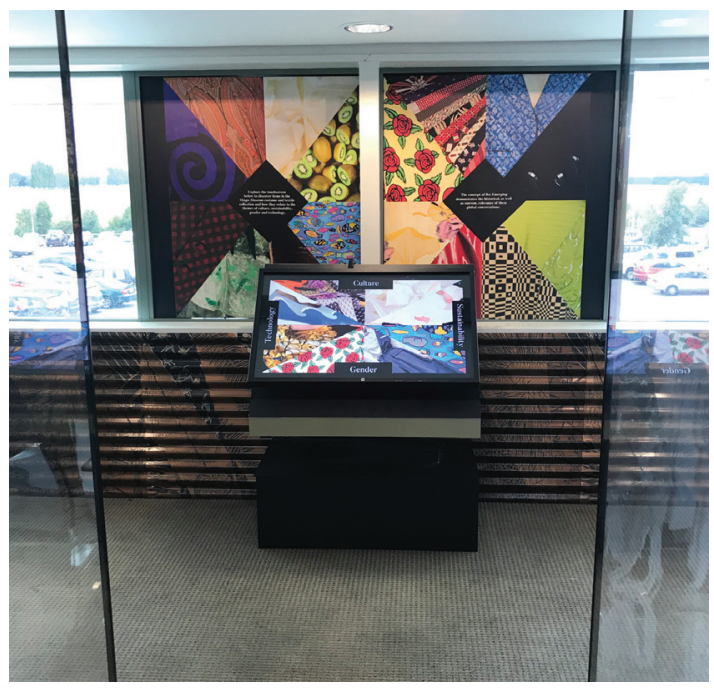

Figure 3. Re:Emerging. The touch screen in situ at Dunedin Airport. Photograph: Courtesy Otago Museum. 
"Contemporary Fashion Practices: A Symposium Exhibition" started its life as a one-day symposium to be held in Dunedin, in conjunction with the 2020 iD International Emerging Designer Awards and iD Dunedin Fashion Week. Its theme was critical making, highlighting innovative and forward-thinking physical material practices in fashion and fashionrelated areas. Having a physical exhibition and symposium was not possible after the arrival of Covid-19, so our strategy switched to creating an online version instead. ${ }^{10}$ The second call for entries indicated that the submissions were to be digital, and attracted quite a number of proposals, which were assessed anonymously and independently, graded for their response to the criteria provided in the call, then collectively collated by Margo, Jane and Moira to make our final selection. We knew that curatorial practice by curator and artist collaborations had developed in the online world since the 1990s, both affiliated to and independent of museum institutions" so we had confidence that it could work, even though we knew it would also take a lot more work and probably cost more than a traditional show.

We asked our selected designers to prepare a 300-500 word abstract, create a short video explaining their rationale and processes of critical making, and provide between three and nine photographs showing their outcomes. In our exhibition (at www. contemporaryfashionpractices.com), the artifacts created by the selected designers are real objects, but they are seen by viewers only virtually, through the website. While many people are now used to shopping for fashion online, we know that experience is not the same thing as seeing textiles or garment details such as seams, prints and drape at first hand. However, there are some upsides: as curators, we can monitor statistics about viewers - for example, their geographical spread, and numbers of views in particular countries. This can be useful information for participants, and website publication of the symposium exhibition can count as a peer-reviewed publication. Additionally, the symposium, which usually only attracts submissions from New Zealand, attracted 35 submissions from 13 countries, giving a much wider view of contemporary fashion practices and critical making.

The curation of "Anything Could Happen: An Exhibition of Contemporary Art and Fashion from Dunedin, New Zealand," which took place at the Yuyuan Gardens exhibition hall (Yu Gallery) in Shanghai, was a collaboration between Margo Barton and Jane Malthus, with Antony Deaker, facilitated through his role at the Dunedin City 
Council. Dunedin has an active sister-city relationship with Shanghai, which includes collaborations by Otago Polytechnic and Shanghai fashion schools, and through this the curators were able to secure the honour of a month at the Yuyuan Garden for this show. ${ }^{12}$ The curators wanted to represent the diversity, quality and connectivity of the many fashion designers and artists who have connections with Dunedin, and were keen to include those who had or were developing a commercial track record and could potentially exhibit other work in China. ${ }^{13}$ The call for entries from Dunedin and Otago artists and fashion designers received almost 200 responses. Five expert judges selected the final 33 works. ${ }^{14}$

At Otago Museum, Moira White and Jane Malthus have worked together on several short-term special exhibitions and other projects. For textiles and dress in museum collections, short-term displays are preferable for conservation reasons. Our collaborations include "Hem and Hair," a 1960s fashion exhibition, in 1992;"Kimono: A Japanese Story," featuring traditional dress gifted to Dunedin by another sister city, Otaru; and "Fashionable Gold," an exhibition that responded to iD Dunedin's "gold"-themed year in 20 I4. (See inventory for a more complete list). We worked with design and exhibition staff to create the 'look' of each exhibition.

"Hem and Hair" featured 1960s men's and women's dress and accessories from the Otago Museum collections in settings such as a wedding, a dance, a café and street scenes where we could use 'shop windows' to display some items. Partly to emphasise the slimness of fashionable bodies in that decade, and because we did not have enough forms or mannequins or budget to purchase more at the time, pipe fittings were used to create stylised anthropomorphic structures to carry the clothes.

"Kimono: A Japanese Story" was a large, crowded installation of the extensive gift that the people of Otaru had sent to Dunedin. It comprised just over 200 men's, women's and children's kimono, yukata, haori and hakama, obi and other accessories that became part of this show. Members of Dunedin's Japanese community helped enormously with identifications, translations and tasks such as pairing kimono and obi appropriately. "Kimono: A Japanese Story" included formal women's mon-tsuki, tomesode, furisode, uchikake, homongi and mourning kimono, as well as less

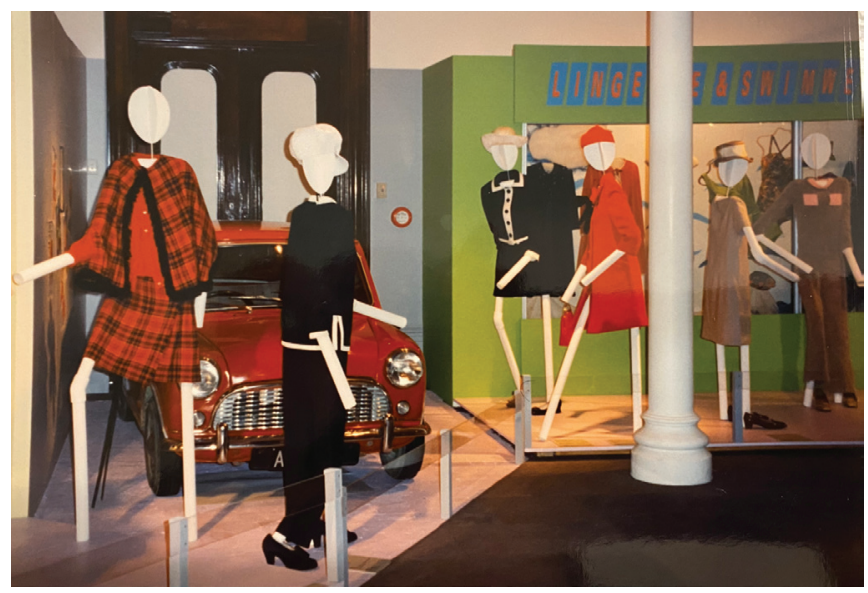

Figure 6. Hem and Hair. We even included an iconic 1960s Mini with the miniskirts. Photograph: Jane Malthus.

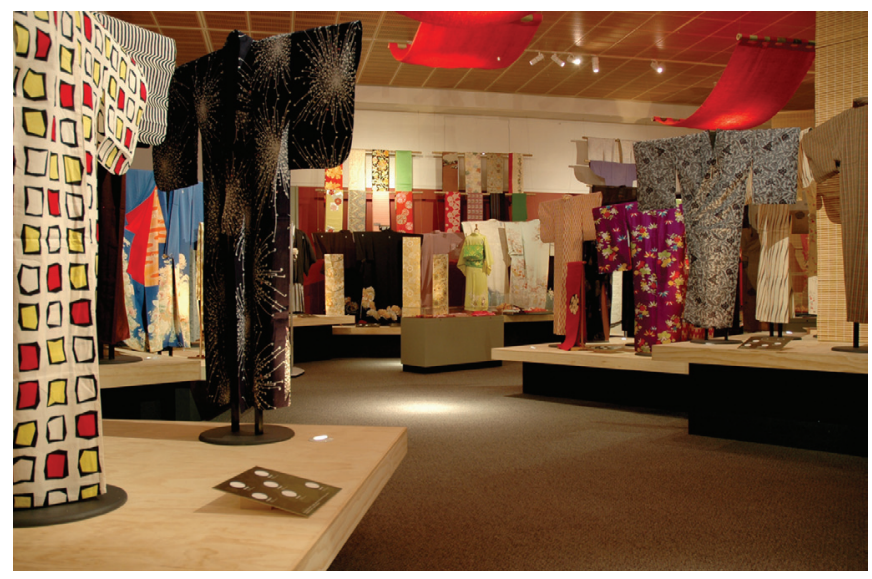

Figure 7. Kimono: A Japanese Story.View of less formal kimono, and obi. Photograph: Courtesy Otago Museum. 
formal fudangi, komon and yukata; men's formal haori and hakama and informal kimono; children's kimono worn for the Shichigosan festive day for three- and sevenyear-old girls and five-year-old boys in November, and other festivals; various inner kimono and many gorgeous obi and other belts and accessories, thanks to the generosity of Otaru citizens. We used T-shaped stands for many kimono and obi, although some complete ensembles were shown in the round. The extensive display allowed us to explain some of the detailed and subtle meanings of patterns and

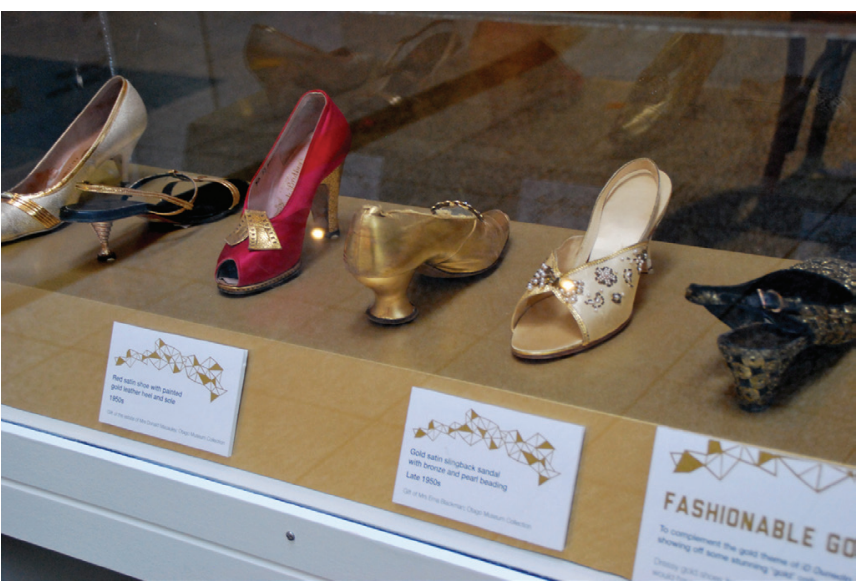

Figure 8. Fashionable Gold. The variety of ways "gold" appears on women's shoes. Photograph: Courtesy Otago Museum. colour in Japanese dress.

"Fashionable Gold" differed from our other exhibitions in that it was shown in spaces spread over three floors of Otago Museum. In the entrance foyer was a case of women's gold-coloured shoes; on the first floor a stand-alone case with an 1882 wedding dress on a dress form; and on the top floor several garments on forms in cases at the entrance to the People of the World gallery. Higher light levels than museum textiles should be exposed to long term were an issue in two of the three spaces, so we had to choose artifacts and position cases carefully, as well as restrict the length of the exhibition.

\section{CONCLUSION}

Our collaborative curatorial practice has been a form of consciousness raising, learning from one another as well as from the practices of others. We are aware that in some respects we share a similar demographic, yet we bring our particular herstories to what we do. And we are all passionate about the power of visual three-dimensional displays of clothes of the past and present to stimulate dialogue, imagination and creativity. Floor talks, question-and-answer sessions, lectures and other public programmes add to this stimulation for those who attend them.

We haven't usually been able to survey exhibition audiences, but we do know that clothes and accessories shows are always popular and often bring in first-time visitors. While we have mostly had to work within constraints of institutions such as Otago Museum and Otago Polytechnic, we try to take different approaches in curating, appealing to diverse and widening audiences, and hopefully encouraging greater boldness in people's own clothing choices and future interest in fashion-related exhibitions and events.

Our agenda also includes promoting discussion about the global fashion industry including its importance for employment, problems of resources and environmental sustainability, ethics and potential for change to slower production cycles. In "Fashion Forward," for example, these subjects are addressed through explicit comments from the emerging designers on the touch screens, interviews with Dunedin designers and 'the godmothers' and through films screening during the tenure of the exhibition. Hopefully, through our exhibits and related talks we can create interfaces for solutions to emerge. 
Jane Malthus is a dress historian and retired academic, specialising in nineteenth- and twentieth-century New Zealand dress history. She has been the honorary curator of the dress collection at Otago Museum since the 1980s. Combining material and social history and culture in her research with a New Zealand focus, she has published work, curated exhibitions and presented papers on topics such as dressmakers in nineteenthcentury New Zealand, waterproof clothing, Otago Museum's lace collection, the Eden Hore Dress collection and Rosaria Hall. She also has a fine arts degree.

Moira White is Curator, Humanities at Otago Museum. She has published and presented papers on various aspects of the museum's collection, including dress and textiles, ceramics, the Antarctic collections, Melanesian material culture and its collectors, the technology collections and museum history. She has curated and cocurated exhibitions on these and other themes.

Margo Barton (ORCID ID: https://orcid.org/0000-000 I-8055-3630) is a fashion educator, researcher and organiser of fashion events, and a curator of fashion in both traditional and non-traditional senses, most notably through her role as creative director of iD Dunedin Fashion Week, and through Citizen Stylist installations. She is commited to expanding the definition of "fashion" within learning and teaching at Otago Polytechnic, and to improving knowledge and interactions between emerging and independent designers and potential wearers. This occurs through various curatorial activities which acknowledge that we curate ourselves and our identities daily. Her curatorial practice occurs in traditional museum and gallery spaces, on the catwalk, online, through interactive installations and, like us all, via her wardrobe. She is also a milliner and fashion designer.

\section{APPENDIX I: OUR COLLABORATIVE EXHIBITIONS AND PUBLICATIONS}

\section{Exhibitions}

Barton, Margo, Jane Malthus, and Moira White, curators. "Fashion Forward >> Disruption through Design." Otago Museum, 26 March - 17 October 2021.

Barton, Margo, Jane Malthus, and Moira White, curators. "Critical Making: Contemporary Fashion Practices" symposium exhibition, 2021. https://www.contemporaryfashionpractices.com:

Barton, Margo, Jane Malthus, and Moira White, curators. "Re: Emerging." Dunedin Airport, April - September 2019.

Barton, Margo, Jane Malthus, and Antony Deaker, curators. "Anything Could Happen: an Exhibition of Contemporary Art and Fashion from Dunedin New Zealand.'YYYuan Garden Exhibition Hall, Shanghai, China, 8 May - 6 June 2017.

Barton, Margo, Jane Malthus, Caroline McCaw, and Leyton Glen, curators. "A Darker Eden: Fashion from Dunedin." Silo Six, Jellicoe St,Auckland, I 7 February - I March 20 I5. (Exhibition created under the auspices of the NZ Fashion Museum.)

White, Moira, and Jane Malthus, curators. "Fashionable Gold." Otago Museum, March - October 20 I 4.

White, Moira, and Jane Malthus, curators. "Freestyle: Swimwear Fashion.” Otago Museum, 2008.

Malthus, Jane, and Moira White, curators. "Kimono: A Japanese Story." Otago Museum, 24 September 2005 - 29 January 2006.

White, Moira, and Jane Malthus, curators. "Clothed in Roses." Otago Museum, People of the World Gallery, 18 December 2004 - 28 March 2005. 
White, Moira, and Jane Malthus, curators. "Collared:The Story ofTies." Otago Museum, 24 February - 19 May 2002.

White, Moira, and Jane Malthus, curators. "Putting the Century to Bed." Otago Museum, October - December 1999.

White, Moira, and Jane Malthus, curators. "Hem and Hair: 1960s Fashions." Otago Museum, 1992.

\section{Related Publications}

Barton, Margo, Jane Malthus, and Moira White.Various contributions to Fashion Fwd >> Disruption through Design. Dunedin: Otago Museum Trust Board and Otago Polytechnic, 2021.

White, Moira, Jane Malthus, and Margo Barton. "The COVID Sidestep." Context: dress/fashion/textiles, 4I (Summer 2020/21), 8-15.

Malthus, Jane, Margo Barton, and Moira White. "Escapism." Otago Daily Times [The Mix], I 8 April 2020.

Malthus, Jane, and Moira White. "The Business of Staying Dry: Designing Waterproof Textiles and Garments in Nineteenth-century New Zealand.' Scope: Contemporary Research Topics: Art and Design, 17 (2019), 23-3I.

Malthus, Jane, Antony Deaker, and Margo Barton. "Anything Did Happen when Dunedin Art and Fashion went to Shanghai." Scope Contemporary Research Topics: Art and Design, 16 (2018), 39-5I.

Malthus, Jane, Margo Barton, Annette Cadogan, and Antony Deaker. "Anything Could, and Did, Happen on an Otago Polytechnic Design Trip to China." Context: dress/fashion/textiles, 35 (Summer 20 I7//8), 28-36.

Barton, Margo, Antony Deaker, and Jane Malthus. Anything Could Happen Catalogue. Dunedin: Otago Polytechnic and Dunedin City Council, 2017 (English and Chinese versions.)

Barton, Margo, Jane Malthus, Annette Cadogan, and Erin Broughton. "Anything Could Happen - A Prime Minister's Scholarship, Asia Fashion Study Tour." Scope: Contemporary Research Topics:Art and Design, I5 [Fashion] (2017), I3-23.

Malthus, Jane, Simon Swale, and Margo Barton, eds. Scope: Contemporary Research Topics: Art and Design 15: Fashion (2017).

Swale, Simon, Jane Malthus, and Margo Barton. "Fashion Today andTomorrow: Considering an Interconnected Global System of Challenges and Promise." Scope: Contemporary Research Topics: Art and Design, 15 [Fashion] (2017), 6-7.

Malthus, Jane, Col Fay, Matthew Galloway, Megan Brasell-Jones, Margo Barton, Gavin O'Brien, and Caroline McCaw. "Art-educated Design Educators." In Art and Design: History, Theory, Practice, eds Peter Stupples and Jane Venis, 193206 (Cambridge, UK: Cambridge Scholars, 20 I7).

Malthus, Jane, Caroline McCaw, Leyton Glen, and Margo Barton. "Interplay and Interplace: A Collaborative Exhibition Addressing Place-based Identity in Fashion Design." In IASDR 2015 Interplay Proceedings, eds V Popovic, A Blackler, D-B Luh, N Nimkulrat, B Kraal and Y Nagai, I 396-I4I 4 (Brisbane: Queensland University of Technology, 20 I5).

Barton, Margo, and Jane Malthus, eds. A Darker Eden: Fashion from Dunedin. Auckland: New Zealand Fashion Museum, 2015.

Malthus, Jane. "A Darker Eden." In A Darker Eden: Fashion from Dunedin, eds Margo Barton and Jane Malthus, 7-9. Auckland: New Zealand Fashion Museum, 2015.

Malthus, Jane. "iD Dunedin," and "Designer Profiles." In A Darker Eden: Fashion from Dunedin, eds Margo Barton and Jane Malthus, 10-27. Auckland: New Zealand Fashion Museum, 2015.

Malthus, Jane, and Moira White. "Making and Doing at Home: Patchwork and Other Sewing Crafts as Occupational Therapy." Scope: Contemporary Research Topics: Health and Wellbeing, 3 (2018), 21 -30.

Malthus, Jane, and Moira White. "Fashionable Gold." Context: dress/fashion/textiles, 28 (2014), 53-56. 
Malthus, Jane, and Moira White. "FURtive Gathering? Contextualizing the Furs in Otago Museum's Collection." Context: dress/fashion/textiles, 26 (Winter 2013), 4I-5I.

Malthus, Jane, and Moira White. "Celebrating the Lace Collection at Otago Museum." Context: dress/fashion/textiles, $23(2011), 8-18$.

White, Moira, and Jane Malthus. "Barker-Eames Collection." Context: dress/fashion/textiles, 17 (July-November 2008), 21.

\section{Calendars}

White, Moira, and Jane Malthus, with Otago Museum designers. Freestyle: Swimwear Fashion 2008 Wall Calendar. Dunedin: Otago Museum, 2007.

White, Moira, and Jane Malthus, with Otago Museum designers. 2006 Wall Calendar featuring artifacts from "Kimono: A Japanese Story." Dunedin: Otago Museum, 2005.

White, Moira, and Jane Malthus, with Otago Museum designers. Ties: 2002 Wall Calendar. Dunedin: Otago Museum, 2001.

White, Moira, and Jane Malthus, with Otago Museum designers. Putting the Century to Bed: 2000 Wall Calendar. Dunedin: Otago Museum, 1999.

I Hazel Clark and Annamari Vänskä, "Introduction: Fashion Curating in the Museum and Beyond," in Fashion Curating: Critical Practice in the Museum and Beyond, eds Annamari Vänskä and Hazel Clark (London: Bloomsbury, 20 I8), I- I5, at 5.

2 See https://www.vanityfair.com/culture/1993/I I/diana-vreeland-1993। I_for a brief biography of Vreeland.

3 Vänskä and Clark, "Introduction."

4 |bid., I.

5 Julia Petrov, "Gender Considerations in Fashion History Exhibitions," in Fashion and Museums: Theory and Practice, eds Marie Riegels Melchior and Birgitta Svensson (London: Bloomsbury, 20I4), 77-90.

6 Annamari Vänskä, "Boutique - Where Art and Fashion Meet: Curation as Collaboration and Cultural Critique," in Vänskä and Clark, Fashion Curating, I19-135, at I31.

7 Vänskä and Clark, Fashion Curating, 2.

8 Pamela Harris Lawton, "Curate, Curate | Curator, Curator: Curatorial Practice in Art Education," Visual Inquiry, 6:I (20।7), 95- 05.

9 Vänskä and Clark, Fashion Curating, back cover.

10 Moira White, Jane Malthus and Margo Barton, "The COVID Sidestep," Context: dress/fashion/textiles, 4I (Summer 2020/2I), 8- I5.

II Christiane Paul,"Flexible Contexts, Democratic Filtering and Computer-aided Curating: Models for Online Curatorial Practice," in Curating, Immateriality, Systems: On Curating Digital Media, ed. Joasia Krysa (New York: Autonomedia Press:, 2006), 85- I05.

12 The exhibition was developed and managed through Enterprise Dunedin in partnership with staff from the Otago Polytechnic School of Fashion and School of Art. Project China and Export Education Project were also involved. Guidance and support were provided by staff at Creative New Zealand and the Ministry of Foreign Affairs and Trade in both New Zealand and Shanghai, as well as by staff at the Yu Yuan Garden, Huangpu District and Shanghai Municipal Government.

13 Jane Malthus, Antony Deaker and Margo Barton, "Anything Did Happen When Dunedin Art and Fashion Went to Shanghai," Scope: Contemporary Research Topics: Art and Design, 16 (2018), 39-51.

14 Ibid., 4 I. 